Volume 2 Nomor 2 Desember 2020:1-8

\title{
KONTRIBUSI HUTAN RAKYAT TERHADAP PENDAPATAN PETANI DI KECAMATAN KABAWO KABUPATEN MUNA
}

\author{
(Contribution of Farm Forestry to Farmer Income in Kabawo District Muna \\ Regency) \\ Musdi $^{1}$, Hardjanto ${ }^{2}$, Dan Leti Sundawati ${ }^{3}$ \\ ${ }^{1}$ Program Studi Ilmu Pengelolaan Hutan Fakultas Kehutanan, Jl. Lingkar Akademik Kampus IPB \\ Dramaga Bogor 16680 \\ ${ }^{23}$ Departemen Manajemen Hutan Fakultas Kehutanan, IPB University, Jl. Lingkar Akademik \\ Kampus IPB Dramaga Bogor 16680 \\ Email: musdi945@gmail.com
}

\begin{abstract}
Farm forestry management is expected to provide economic benefits for improving the community welfare. It is shown from the result of farm forestry contribution. Cropping pattern selection can be a supporting factor for the success of managing farm forestry. It intends to increase the contribution of farm forestry to farmers income. This study aims to calculate the contribution of farm forestry to farmers income by the applied cropping pattern. The sampling method was used purposive sampling method with a total of 100 respondents who are the farm forestry farmers lived in Kabawo District. The results showed that cropping pattern of farm forestry in Kabawo District consists of 3 types which are monoculture, mixed garden and agroforestry with $81 \%$ of farmers adopted monoculture cropping pattern. This cropping pattern was chosen because it does not require a lot of treatment. Farm forestry income has contributed $7.25 \%$ of the average total income of farmer families per year. The low contribution of farm forestry is affected by the farm forestry business position which is still seen as a side job and the area for planting is relatively small.
\end{abstract}

Keywords: Farm Forestry, Contribution, Cropping Pattern

\begin{abstract}
ABSTRAK
Pengelolaan hutan rakyat diharapkan mampu memberikan manfaat ekonomi yang dapat meningkatkan kesejahteran masyarakat. Hal tersebut dapat dilihat dari kontribusi hutan rakyat yang dihasilkan. Pemilihan pola tanam dapat menjadi faktor pendukung didalam keberhasilan mengelola hutan rakyat. Tujuannya adalah untuk meningkatkan kontribusi hutan rakyat terhadap pendapatan petani. Penelitian ini bertujuan untuk menghitung kontribusi hutan rakyat terhadap pendapatan petani dengan pola tanam yang diterapkan. Metode pengambilan sampel yang digunakan adalah purposive sampling dengan jumlah responden 100, yang merupakan petani hutan rakyat yang berdomisili di Kecamatan Kabawo. Hasil penelitian menunjukan bahwa bentuk pola tanam hutan rakyat di Kecamatan Kabawo terdiri atas 3 macam yaitu monokultur, kebun campuran dan agroforestry dengan $81 \%$ petani mengadopsi pola tanam monokultur. Pola tanam ini dipilih karena dalam perawatannya tidak membutuhkan perlakuan yang banyak. Kontribusi pendapatan hutan rakyat adalah 7,25\% dari rata-rata pendapatan total keluarga petani per tahun. Rendahnya kontribusi hutan rakyat disebabkan oleh usaha hutan rakyat masih merupakan pekerjaan sampingan dan luas lahan yang digunakan tergolong kecil.
\end{abstract}

Kata kunci: Hutan Rakyat, Kontribusi, Pola Tanam 


\section{PENDAHULUAN}

Hutan rakyat merupakan bentuk pengelolaan sumber daya alam yang bertujuan untuk menghasilkan kayu atau komoditas lain sehingga diharapkan dapat meningkatkan pendapatan dan kesejahteraan masyarakat. Hutan rakyat dapat menjadi salah satu alternatif pemecahan masalah terhadap tekanan sumber daya hutan dengan manfaat yang bisa diperoleh dari pengelolaannya antara lain pemenuhan kebutuhan kayu, peningkatan pendapatan masyarakat, peningkatan produktivitas lahan milik masyarakat serta pemenuhan kebutuhan pangan (Irundu dan Fatmawati, 2019; Pratama et al. 2015). Pola pendekatan ekonomi atau pola pendekatan kelestarian alam merupakan pilihan yang perlu dipertimbangkan dalam penatausahaan hasil hutan kayu rakyat dan diharapkan terwujudnya hutan rakyat yang efektif dan efisien (Syahadat dan Dwiprabowo 2008). Hutan rakyat sangat memungkinkan untuk dapat meningkatkan pendapatan dan mengembangkan kesejahteraan petani (Saraswati dan Darmawan, 2014).

Masyarakat di Kecamatan Kabawo menerapkan usaha hutan rakyat untuk memperoleh kontribusi berupa hasil usaha yang mampu meningkatkan pendapatan masyarakat dalam mencukupi kebutuhan sehari-hari. Perlu ada kajian tentang bagaimana bentuk pengelolaan hutan rakyat guna mengetahui seberapa besar kontribusi hutan rakyat terhadap pendapatan petani. Berdasarkan hal tersebut penelitian ini bertujuan untuk mengetahui kontribusi hutan rakyat terhadap pendapatan petani di Kecamatan Kabawo Kabupaten Muna Provinsi Sulawesi Tenggara. Penelitian ini diharapkan dapat memberikan informasi kepada masyarakat dan pemerintah daerah tentang kontribusi hutan rakyat, sehingga dapat membangun kesadaran untuk mengoptimalkan pengelolaan hutan rakyat.

\section{METODE PENELITIAN}

Penelitian ini dilaksanakan selama tiga bulan dari bulan Oktober sampai Desember 2018. Penelitian lapangan dilakukan di Kecamatan Kabawo Kabupaten Muna Sulawesi Tenggara. Pemilihan lokasi penelitian dilakukan secara purposive. Metode pengambilan sampel/ responden yang digunakan adalah purposive sampling dengan jumlah responden 100, yang merupakan petani hutan rakyat yang berdomisili di Kecamatan Kabawo. Pengumpulan data dilakukan dengan empat cara yaitu wawancara kuisioner, observasi dan studi Pustaka.

Perhitungan pendapatan rumah tangga petani sebagai pendekatan kesejahteraan (Sudrajat 2015) dihitung dengan menggunakan rumus:

Prtp $=P h r+P n h r$

Keterangan:

Prtp : Pendapatan rumah tangga petani (Rp/thn)

$\mathrm{Phr}$ : Pendapatan dari pengelolaan hutan rakyat ( $\mathrm{Rp} / \mathrm{thn})$

Pnhr : Pendapatan dari non hutan rakyat (Rp/thn)

Kontribusi pengelolaan hutan rakyat terhadap pendapatan rumah tangga petani:

$$
\% \mathrm{Phr}=\frac{\mathrm{Phr}}{\mathrm{Prtp}} \quad \mathrm{x} 100 \%
$$

Keterangan :

$\%$ Phr: Persentase pendapatan dari pengelolaan hutan rakyat (\%)

$\mathrm{Phr}$ : Pendapatan dari pengelolaan hutan rakyat pertahun (Rp/tahun)

Prtp : Pendapatan rumah tangga per tahun (Rp/thn)

\section{HASIL DAN PEMBAHASAN}

Ada tiga jenis pola tanam yang digunakan oleh petani hutan rakyat di Kecamatan Kabawo yaitu pola monokultur, kebun campuran dan agroforestry. Pola tanam ditujukan untuk mengoptimalkan luas bidang lahan yang ada agar lebih 
bermanfaat. Ada beberapa pola tanam yang dikenal di dalam pengelolaan hutan rakyat yaitu pola monokultur, kebun campuran dan agroforestry (Lembaga Penelitian IPB 1983; Sutisna 2015; Hudiyani et al. 2017). Selain itu, kondisi biofisik Kecamatan Kabawo yang merupakan daerah dataran rendah yang kurang 200 mdpl memberikan manfaat lebih dengan keanekaragaman pola tanam. Semakin rendah topografi tempat tumbuh, pola tanam dan jenis tanaman yang dikembangkan semakin beragam (Achmad dan Purwanto 2014). Kondisi biofisik merupakan aspek yang berkaitan dengan kesesuaian jenis tanaman dengan ketinggian/ tanah dan kelembaban di wilayah setempat. Hal ini sejalan dengan studi yang dilakukan oleh Assogbadjo et al. (2012); Norgrove dan Hauser (2016); Nyagumbo et al. (2017) bahwa petani memiliki kriteria biofisik yang disesuaikan dengan sistem penanaman yang dilakukannya

Pola monokultur adalah pola yang paling banyak digunakan petani di Kecamatan Kabawo di dalam budidaya hutan rakyat mencapai $81 \%$. Pola tanam ini dipilih karena dianggap lebih simpel, membutuhkan perlakuan yang sama terhadap tanaman. Lahan yang digunakan petani juga di anggap tidak produktif untuk membudidayakan tanaman pertanian. Lokasi yang jauh dari pemukiman petani serta ancaman dari hewan liar seperti babi hutan dan kera merupakan salah satu faktor yang menyebabkan petani tidak membudidayakan tanaman buah untuk dikombinasikan dengan jati. Volume kayu yang dihasilkan akan lebih banyak dan kualitas yang lebih baik. Selain itu, petani hutan rakyat merupakan pekerjaan sampingan yang digeluti. Sebagian besar responden memiliki pekerjaan utama di luar bertani dengan persentase mencapai $61 \%$. Pekerjaan utama diluar bertani menyebabkan minimnya waktu luang untuk mengurus lahan sehingga hutan rakyat dengan pola tanam monokultur dianggap lebih cocok untuk dikembangkan.

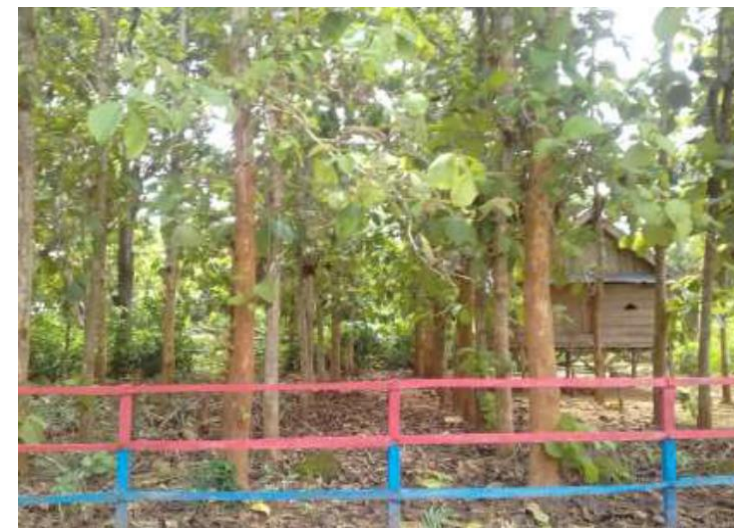

Gambar 1. Pola monokultur

Kebun campuran merupakan salah satu pola tanam yang di adopsi petani di lokasi penelitian. Salah satu ciri pola tanam ini yaitu tidak terdapat jarak tanam (secara acak) antara pohon yang satu dengan pohon lainnya. Pohon jati biasanya dijadikan sebagai tanaman pagar/pembatas antara kebun serta tanaman pengisi lahan yang kosong. Kebun campuran petani terdiri atas berbagai tanaman seperti Jambu Mete (Anacardium Occidentale), Kelapa (Cocos Nucifera), Kapuk (Ceiba Pentandra), Aren/enau (Arenga Pinnata), Coklat/kakao (Thebroma Cacao), dan Mangga (Mangifera Indica). Tanaman-tanaman tersebut sengaja dibudidayakan oleh petani karena memberikan manfaat yang besar dan hasilnya dapat dirasakan setiap tahunnya. Beberapa tanaman jenis lain, berupa tanaman tahunan dan atau tanaman setahun yang tumbuh sendiri maupun ditanam, dibiarkan hidup di kebun campuran selama tidak mengganggu tanaman pokok (Martini et al. 2010).

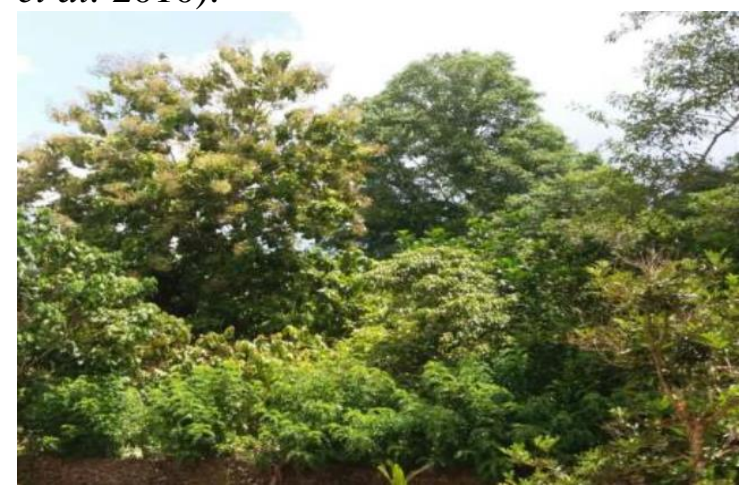

Gambar 2. Pola kebun campura 
Berdasarkan pengetahuan lokal yang masyarakat miliki, agroforestry telah diaplikasikan di lahan-lahan kering hutan rakyat (Sudomo dan Hani 2014). Jenis tanaman yang dikombinasikan dengan jati adalah jagung dan kacang tanah. Pemilihan dua jenis tanaman ini dianggap mudah beradaptasi dengan kondisi lahan yang ada serta memiliki masa panen dua kali dalam setahun. Jagung merupakan makanan pokok yang dikonsumsi oleh petani selain ubi kayu (singkong). Namun masih sebagian kecil petani mengadopsi pola tanam ini. Salah satu faktor penyebab minimnya petani menggunakan pola agroforestry karena sebagian besar petani membersihkan lahan masih menggunakan obat rumput/bahan kimia dan dengan cara membakar. Penggunaan bahan kimia dan pembakaran dikhawatirkan dapat berdampak pada tanaman lain yang menyebabkan kematian.

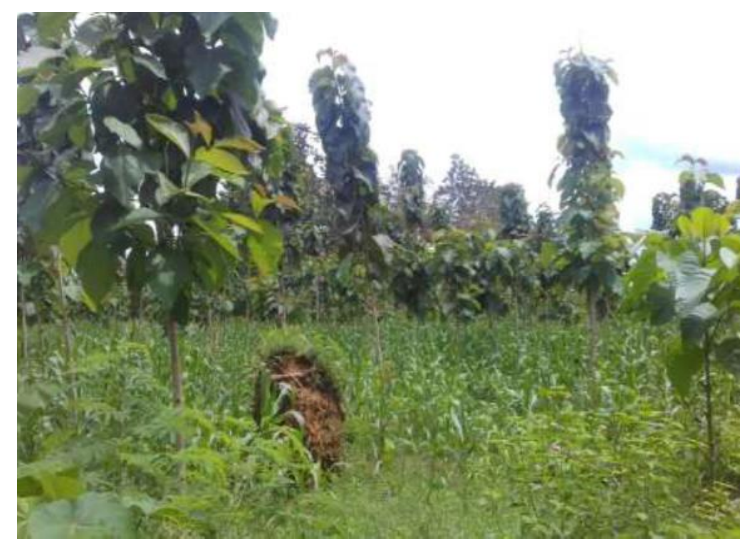

Gambar 3. Pola agroforestry

Jarak tanam yang umum untuk jenis tanaman jati di lokasi penelitian adalah $3 \times 3$ $\mathrm{m}$ dan $4 \times \mathrm{x} 4 \mathrm{~m}$ dengan pola tanam monokultur dan agroforestry. Namun ada beberapa lokasi yang menerapkan pola kebun campuran yang tidak menggunakan jarak tanam. Jarak tanam digunakan berdasarkan insting dan keadaan lahan. Jarak tanam dapat mempengaruhi karakteristik pertumbuhan pohon tetapi tidak mempengaruhi sifat-sifat kayu. Wahyudi et al. (2014) menyatakan bahwa jarak tanam yang lebih lebar cenderung menghasilkan pohon yang diameternya lebih besar tetapi memiliki tinggi bebas cabang yang lebih pendek dan jumlah percabangan yang lebih banyak. Pengaturan jarak tanam jati oleh petani berdasarkan insting bertujuan untuk meminimalkan kemungkinan terjadinya persaingan akar dalam penyerapan unsur hara dan penyerapan sinar matahari oleh daun.

Sebagian besar petani mengusahakan hutan rakyat dengan tanaman utamanya adalah jati yang didorong oleh nilai jual tinggi serta kualitas kayu jati yang dianggap baik. Selain itu, jati di anggap sebagai tanaman yang mencirikan khas daerah. Tahun 2000-2010 merupakan tahun puncak yang menempatkan kayu jati sebagai produk kayu idola bagi masyarakat Kabupaten Muna yang kabarnya tersebar dimana-mana. Pada tahun yang sama pula, terjadi degradasi hutan jati muna secara besar-besaran. Makin menipisnya ketersediaan kayu serta makin meningkatnya kebutuhan kayu jati mendorong masyarakat untuk mengusahakan tanaman jati di lahannya yang kurang produktif untuk dijadikan hutan rakyat jati.

Jati bukan merupakan satu-satunya jenis tanaman kehutanan yang dibudidayakan di lahan milik petani. Berdasarkan data yang dikeluarkan Dinas Kehutanan Kabupaten Muna tahun 2012, ada 4 jenis tanaman lain yang dibudidayakan oleh petani sebagai hutan rakyat. Jenis tanaman kehutanan yang dimaksud antara lain Jabon (Anthocephalus spp), Jati putih (Gmelina Arborea), Sengon (Paraserianthes Falcataria) dan Biti (Vitex Cofassus). Jumlah tanaman jati yang dibudidayakan petani hutan rakyat di lahan milik yang dikelola mencapai $91,87 \%$. Artinya ada sekitar $8,13 \%$ jumlah tanaman lain selain jati yang dibudidayakan oleh petani.

Tabel 1. Pendapatan petani di lokasi penelitian

\begin{tabular}{ccccc} 
Pendapatan & \multicolumn{2}{c}{ Hutan Rakyat } & \multicolumn{2}{c}{ Rumah Tangga } \\
\cline { 2 - 5 }$(\mathrm{Rp} / \mathrm{bln})$ & Jumlah $(\mathrm{n})$ & Persentase $(\%)$ & Jumlah $(\mathrm{n})$ & Persentase $(\%)$ \\
\hline
\end{tabular}




\begin{tabular}{ccccc}
\hline & & & \multicolumn{2}{c}{ Volume 2 Nomor 2 Desember 2020:1-8 } \\
\hline$<$ Rp 1 juta & 24 & 100 & 7 & 7 \\
Rp 1-4juta & - & - & 78 & 78 \\
$>$ Rp 4 juta & - & - & 15 & 15 \\
\hline Jumlah & 24 & 100 & 100 & 100 \\
\hline Sumber: & Data & primer, & diolah & 2018
\end{tabular}

Tujuan utama dari kelestarian hasil dan usaha hutan rakyat untuk menunjang perekonomian rumah tangga petani. Perekonomian petani diharapkan dapat terbantu dengan adanya pendapatan hutan rakyat. Berdasarkan hasil penelitian, ratarata pendapatan petani dari hutan rakyat jati di Kecamatan Kabawo hanya sebesar Rp 2.194.003 pertahun. Jumlah tersebut hanya menyumbang sekitar $7,25 \%$ dari rata-rata pendapatan total keluarga petani per tahun. Kecilnya kontribusi pendapatan hutan rakyat bagi pendapatan petani secara keseluruhan disebabkan oleh jumlah petani yang telah merasakan hasil dari pemanenan kayu jati hanya 24 orang dari total petani 100 orang atau sekitar $24 \%$ saja. Jumlah tanaman yang diusahakan tiap lahan juga tergolong sedikit. Kontribusi hutan rakyat yang sangat kecil terhadap pendapatan petani juga sejalan dengan hasil penelitian Widyaningsih dan Diniyati (2010) di Kabupaten Cilacap dengan 4,69\% dan Sudrajat (2015) yang dilakukan di dua desa yang berada di Kabupaten Kuningan yakni Desa Cikeusal sebesar 1,9\% dan Desa Kananga 4,2\%.

Beberapa hasil penelitian terkait kontribusi hutan rakyat terhadap pendapatan petani jauh lebih baik dari hasil penelitian di atas. Hasil penelitian lain menyebutkan bahwa pendapatan dari hutan rakyat memberikan kontribusi tidak sedikit yakni mencapai $6 \%-35,79 \%$. Hasil penelitian dari Aminah (2013) yang menyatakan bahwa keuntungan petani hutan rakyat antara $70,54 \%$. Setyadi (2009) juga menyebutkan bahwa kontribusi hutan rakyat terhadap pendapatan total rata-rata petani mencapai $17,87 \%$ - 20,30\%. Selain itu penelitian yang dilakukan Attar (2000) di Desa Sumberejo Kabupaten Wonogiri, tercatat bahwa kontribusi rata-rata petani hutan rakyat bisa mencapai 21,97\%. Bahkan dengan penerapan pola Pengelolaan Hutan Bersama
Masyarakat (PHBM), bisa menghasilkan persentase pendapatan per bulan cukup besar. Aji et al. (2014) mencatat bahwa dengan pola PHBM yang dilakukan petani di Kecamatan Japara Kabupaten Kuningan, pendapatan per bulan dari kayu besar $35,79 \%$, non kayu $54,45 \%$, palawija $5,03 \%$ dan upah banjar harian $4,71 \%$. Hasil penelitian tersebut menjelaskan bahwa kontribusi hutan rakyat terhadap pendapatan total rata-rata petani beraneka ragam. Tergantung berbagai faktor-faktor di dalamnya yang saling berkaitan satu sama lain.

Rendahnya kontribusi hutan rakyat terhadap pendapatan petani bukan sebuah indikasi bahwa pengelolaan hutan rakyat tidak memberikan pengaruh yang baik terhadap petani. Idealnya, semakin luas lahan yang dimiliki petani maka peluang untuk memperoleh keuntungan dari hutan rakyat semakin besar pula. Namun faktanya rata-rata luas lahan yang dimiliki petani pengelola hutan rakyat di Kecamatan Kabawo sekitar 0,83 ha. Skala usaha (luas) yang optimum dapat mempengaruhi pendapatan dari hutan rakyat. Pada kasus hutan rakyat kayu pulp (Acasia mangium) skala ekonomis diperoleh jika luasan lebih dari 6 ha per KK (Rochmayanto dan Supriadi 2012) dan pada pola PHBM diperlukan luas minimum 3,45 ha untuk memperoleh keuntungan yang memadai (Aji et al. 2014).

Masalah tentang kepemilikan lahan sempit sebenarnya bisa di atasi dengan mengoptimalkan luas lahan yang ada, salah satunya dengan pola diversifikasi. Petani hutan rakyat dapat melakukan strategi diversifikasi untuk jenis tanaman penyusunnya untuk meningkatkan hasil. Diversifikasi ini bisa dilakukan dengan penerapan sistem agroforesti oleh petani. Oktalina et al. (2015) menjelaskan bahwa 
sistem agroforestry merupakan strategi diversifikasi yang dilakukan petani dalam mengoptimalkan penggunaan lahan hutan rakyat guna memenuhi hidupnya seperti yang diterapkan oleh petani di Kabupaten Gunung Kidul. Kontribusi hutan rakyat terhadap petani mencapai $13 \%$ - 40\%. Usaha hutan rakyat yang menerapkan pola tumpang sari atau agroforestry dapat menambah penghasilan bagi petani untuk setiap musim tanamnya (Pranamulya et al. 2013). Sistem agroforestry dapat dimanfaatkan sebagai penghasil bahan pangan, pakan ternak, madu, bahan bangunan, bahan obat dan mitigasi tanah longsor (Rendra et al. 2016). Selain strategi diversifikasi upaya peningkatan produktivitas dapat dilakukan dengan perbaikan teknis silvikultur/budidaya dan modifikasi pola tanam yaitu dengan mengatur perbandingan komposisi antara pohon kayu-kayuan dengan buah-buahan dan jenis pohon yang diusahakan (Widiarti dan Prajadinata 2008).

\section{KESIMPULAN}

Bentuk pola tanam hutan rakyat di Kecamatan Kabawo terdiri atas 3 macam yaitu monokultur, kebun campuran dan agroforestry dengan jarak tanam $3 \times 3 \mathrm{~m}, 4$ x $4 \mathrm{~m}$, dan tidak beraturan. $81 \%$ petani mengadopsi pola tanam monokultur. Pola tanam ini di pilih karena didalam perawatannya tidak membutuhkan perlakuan yang banyak. Kontribusi pendapatan hutan rakyat adalah $7,25 \%$ dari rata-rata pendapatan total keluarga petani per tahun. Rendahnya kontribusi hutan rakyat disebabkan oleh usaha hutan rakyat masih merupakan pekerjaan sampingan dan luas lahan tergolong kecil.

\section{DAFTAR PUSTAKA}

Achmad B, Purwanto RH. 2014. Peluang adopsi system agroforestry dan kontribusi ekonomi pada berbagai pola tanam hutan rakyat di Kabupaten Ciamis. Jurnal Bumi Lestari. 14(1): 15-26.
Aji GB, Suryanto J, Yulianti R, Wirati A, Abdurrahman AY, Miranda TI. 2014. Strategi pengurangan kemiskinan di desa-desa sekitar hutan: pengembangan model PHBM dan HKm. Laporan Penelitian. Pusat Penelitian Kependudukan. Jakarta (ID). Lembaga Ilmu Pengetahuan Indonesia.

Aminah LN, Qurniati R, Hidayat W. 2013. Kontribusi hutan rakyat terhadap pendapatan petani di Desa Buana Sakti Kecamatan Batanghari Kabupaten Lampung Timur. Jurnal Sylva Lestari. 1(1): 47-54.

Assogbadjo AE, Kakaï, RG, Vodouhê FG, Djagoun CAMS, Codjia JTC, Sinsin B. 2012. Biodiversity and socioeconomic factors supporting farmers' choice of wild edible trees in the agroforestry systems of Benin (West Africa). Forest Policy and Economics. 14(1): 41-49.

Attar M. 2000. Hutan Rakyat: Kontribusi terhadap pendapatan rumah tangga petani dan perannya dalam perekonomian desa (Kasus di Desa Sumberejo Kab. Wonogiri, Jawa Tengah. Di dalam: Suharjito D, editor. Hutan Rakyat di Jawa. Bogor (ID). Fakultas Kehutanan IPB.

Hudiyani I, Purnaningsih N, Asngari PS, Hardjanto. 2017. Persepsi petani terhadap hutan rakyat pola agroforestry di Kabupaten Wonogiri Provinsi Jawa Tengah. Jurnal Penyuluhan. 13(1).

Irundu, Fatmawati. 2019. Potensi Hutan Rakyat Sebagai Penghasil Pangan di Desa Paku Kabupaten Polman Sulawesi Barat. Jurnal Hutan dan Masyarakat. 11(1): 41-48.

Lembaga Penelitian IPB. 1983. Studi Kelayakan Usaha Tani Hutan Rakyat di Propinsi Jawa Barat. Bogor (ID). Lembaga Penelitian IPB.

Martini E, Tata HL, Mulyoutami E, Tarigan J, Rahayu S. 2010. Membangun kebun campuran. Bogor (ID). ICRAF World Agroforestry Center. 
Norgrove L, Hauser S. 2016. Biophysical criteria used by farmers for fallow selection in West and Central Africa. Ecological Indicators. 61: 141-147.

Nyagumbo I, Mkuhlani S, Mupangwa W, Rodriguez D. 2017. Planting date and yield benefits from conservation agriculture practices across Southern Africa. Agricultural Systems. 150: 21-33.

Oktalina SN, Awang SA, Suryanto P, Hartono S. 2015. Strategi petani hutan rakyat dan konstribusinya terhadap penghidupan di Kabupaten Gunungkidul. Kawistara. 5(3): 221328.

Pramono AA, Fauzi MA, Widyani N, Heriansyah, Roshetko JM. 2010. Pengelolaan hutan jati rakyat. Bogor (ID): Forest Watch Indonesia.

Pranamulya AS, Syafruddin O, Setiawan W. 2013. Nilai ekonomi tumpang sari pada hutan rakyat (Studi kasus di kawasan hutan rakyat Tembong Podol Desa Rambatan Kecamatan Ciniru Kabupaten Kuningan). Wanaraksa. 7(1)

Pratama AR., Yuwono SB, Hilmanto R. 2015. Pengelolaan hutan rakyat oleh kelompok pemilik hutan rakyat di Desa Bandar Dalam Kecamatan Sidomulyo Kabupaten Lampung Selatan. Jurnal Sylva Lestari. 3(2): 99-112.

Rendra PPR, Sulaksana N, Alam BY. 2016. Optimalisasi pemanfaatan system agroforestry sebagai bentuk adaptasi dan mitigasi tanah longsor. Bulletin of Scientific Contribution. 14(2): 117-126.

Rochmayanto Y, Supriadi R. 2012. Skala ekonomis usaha hutan rakyat kayu pulp di Kabupaten Kuantan Singingi, Propinsi Riau. Jurnal Penelitian
Volume 2 Nomor 2 Desember 2020:1-8 Sosial dan Ekonomi Kehutanan. 9 (2): 87-95.

Saraswati Y, Dharmawan AH. 2014. Resiliensi nafkah rumah tangga petani hutan rakyat di Kecamatan Giriwoyo Wonogiri. Jurnal Sosiologi Pedesaan, 71-84

Setyadi LB. 2009. Analisis kelayakan usaha dan kontribusi pengelolaan hutan rakyat Koperasi Hutan Jaya Lestari, Kabupaten Konawe Selatan, Propinsi Sulawesi Tenggara. [skripsi]. Bogor (ID). Institut Pertanian Bogor

Sudomo A, Hani A. 2014. Produktivitas talas dibawah tiga jenis tegakan dengan sistem agroforestry di lahan hutan rakyat. Jurnal Ilmu Kehutanan. 8(2): 100-107.

Sudrajat A. 2015. Partisispasi petani dalam pengelolaan hutan rakyat lestari. [tesis]. Bogor (ID): Institut Pertanian Bogor.

Sutisna. 2015. Analisis finansial usaha hutan rakyat pola monokultur, campuran dan agroforestry di Kabupaten Tanah Laut Kalimantan Selatan. Jurnal Hutan Tropis. 3(2): 124-132.

Wahyudi I, Sinaga DKD, Muhran, Jasni LB. 2014. Pengaruh jarak tanam terhadap pertumbuhan pohon dan beberapa sifat fisis-mekanis kayu jati cepat tumbuh. Jurnal Ilmu Pertanian Indonesia. 19(3): 204-210.

Widiarti A, Prajadinata. 2008. Karakteristik hutan rakyat pola kebun campuran. Jurnal Penelitian Hutan daan Konservasi Alam. 5(2): 145-156.

Widyaningsih TS, Diniyati D. 2010. Konstribusi ekonomi dan sistem pemasaran hasil hutan rakyat pola wanafarma di Majenang Cilacap. Jurnal Penelitian Sosial dan Ekonomi Kehutanan. 7(1): 55-71 